\title{
RELIABILITY OF BARR, LEECH, AND BLETHYN SCORE IN USING OF PLAIN RADIOGRAPHY IN DETERMINING FECAL IMPACTION IN CHILDREN WITH AND WITHOUT CONSTIPATION
}

\author{
Afshin REZAZADEH ${ }^{1}$, Hazhir JAVAHERIZADEH ${ }^{2}$, Farzaneh CHAHARDAHCHERIK ${ }^{3}$, \\ Mohammad Hossein YAVARAHMADI ${ }^{4}$, Nooshin SADJADEI² and Morteza TAHMASEBI ${ }^{1}$
}

Received 9/1/2016 Accepted 4/3/2016

\begin{abstract}
Background - Several scoring was developed for evaluation of children with fecal retention using plain radiograph. There are controversies about specificity and sensitivity of these scoring system. Objectives - The aim of this study was to evaluate Barr, Blethyn, and Leech score in evaluation of fecal load in plain radiograph. Methods - This case control study was conducted on children aged 2-14 years old with abdominal pain who visited Abuzar children's Hospital of Ahvaz University of Medical Sciences. This study was conducted in fall season. Children with history of previous abdominal surgery, any systemic illness including sickle cell anemia were excluded. Children with constipation were placed in case group. Subjects without constipation were placed in control group. Subjects without exclusion criteria were examined by physician who is blind to aim of the study. Careful history and physical examination was done. Demographic features, history of gastrointestinal problem, duration of abdominal pain, defecation habit, stool consistency (loose, hard), and results of physical examination were recorded. Rome III criteria was used for definition of constipation. Abdominal x-ray was ordered for each patients. Abdominal radiography was reviewed by radiologist. Barr, Leach, and Blethyn scores were calculated for each case. Results - In this study 102 children with functional constipation and 102 children without constipation as a control were included. Mean \pm SD for case and control group was $68.39 \pm 34.88$ and $69.46 \pm 32.60(P=0.82)$. Leech score (mean $\pm \mathrm{SD}$ ) was $11.05 \pm 2.177$ and $5.67 \pm 3.228$ for case and control group respectively $(P<0.0001)$. Barr score (mean $\pm \mathrm{SD})$ was $14.86 \pm 3.54$ and $7.16 \pm 5.59$ for case and control group respectively $(P=<0.0001)$. Blethyn (mean \pm SD) score was $1.97 \pm 0.667$ and $1.04 \pm 0.900$ for case and control group respectively $(P=0.000)$. Sensitivity and specificity of Barr score was $83 \%$ and $79 \%$ respectively. Sensitivity and specificity of Leech score was $92 \%$ and $80 \%$ respectively. Sensitivity and specificity of Blethyn score was $79 \%$ and $92 \%$ respectively. Conclusion - Barr, Blethyn and Leech scores were significantly higher in children with abdominal pain and constipation in contrast to children with abdominal pain and without constipation. Sensitivity of Leech score was more than Barr and Blethyn scoring systems. Specificity of Blethyn score was more than Barr and Leech score.

HEADINGS - Constipation. Child health. Abdominal pain. X-ray. Encopresis. Fecal impaction.
\end{abstract}

\section{INTRODUCTION}

Constipation is a frequent gastrointestinal problem in children which has a prevalence between $16-34 \%$ in different studies $^{(9,10,17,18,19)}$.

History and careful physical examination are sufficient for diagnosis of functional constipation, but some physician ordered abdominal x-ray for evaluation of fecal material which was impacted in the abdomen ${ }^{(6,8,14)}$.

We saw many cases from low socio economic status who are not collaborative for history and physical examination. In these cases, diagnosis of constipation according to Rome III criteria are not possible. In these case, plain roentgenogram may be helpful for assessment of fecal load.
In the study by Barr et al. on 30 children with constipation and 12 children without constipation, sensitivity and specificity of radiologic evaluation was $80 \%$ and $90 \%$ respectively ${ }^{(1)}$.

In another study by Leech et al., there was significant difference between scores of children with constipation and without constipation with sensitivity and specificity which was $76 \%$ and $75 \%$ respectively ${ }^{(13)}$.

In a systematic review by Berger et al., they did not find sufficient evidence for role of plain abdominal $\mathrm{x}$-ray in diagnosis of functional constipation in children $^{(4)}$. There was a controversy regarding reliability of three scoring system. Plain abdominal radiograph is a simple method which omit stressful examination, digital rectal examination, for uncooperative child.

Declared conflict of interest of all authors: none

Disclosure of funding: no funding received

Limitation: Post treatment evaluation is lacking

Department of Radiology School of Medicine, Ahvaz Jundishapur University of Medical Sciences, Ahvaz, Iran; ${ }^{2}$ Nursing Care Research Center in Chronic Diseases and Dept. of Pediatric Gastroenterology, School of Medicine, Ahvaz Jundishapur University of Medical Sciences, Ahvaz, Iran; ${ }^{3}$ Student Research Committee Ahvaz Jundishapur University of Medical Sciences, Ahvaz, Iran; ${ }^{4}$ Student Research Committee, Tehran University of Medical Sciences, Tehran, Iran.

Correspondence: Farzaneh Chahardahcherik. Student Research Center, Ahvaz Jundishapur University of Medical Sciences, Ahvaz 61956, Iran. E-mail: dr_frz85@yahoo.com 
Because these controversies and there was no such study in our country, the current study was carried out to reevaluate these scoring system in diagnosis of stool impaction using Barr, Blethyn, and Leech score.

\section{METHODS}

This case control study was conducted on children aged 2-14 years old with abdominal pain who visited Abuzar children's hospital of Ahvaz university of medical sciences. Children with constipation were placed in case group. Children without constipation were placed in control group. This study was conducted in fall season. Children with history of previous abdominal surgery, any systemic illness including sickle cell anemia were excluded. Subjects without exclusion criteria were examined by physician who is blind to aim of the study. Careful history and physical examination was done. Demographic features, history of gastrointestinal problem, duration of abdominal pain, defecation habit, stool consistency (loose, hard), and results of physical examination were recorded.

Rome III criteria was used for definition of constipation ${ }^{(9,18)}$.

Abdominal x-ray was ordered for each patients. Abdominal radiography was reviewed by radiologist. Barr ${ }^{(1)}$, Leach ${ }^{(13)}$, and Blethyn ${ }^{(5)}$ scores were calculated for each case.

Bar et al. developed a scoring system based on both the quality and quantity of stool in the ascending, transverse, descending colon and rectum (Barr et al., 1979). "The quantity of stool in ascending ( 0,1 or 2 points), transverse $(0,2$ or 5 points) and descending colon $(0,3$, 4 , or points) and the rectum ( 0,2 or 5 points) is assessed and summated. The quality of the retained stool is expressed in scybala $(0,1,2$, or 3 points) and granular feces $(0,2,4$, or 5 points $)$. A total sum of more than 10 points indicates constipation.

A simplified scoring method is provided by Blethyn et al. ${ }^{(5)}$. They classified plain abdominal radiographs using a diagram with four different grades of fecal loading. Grade 0 (normal) describes the presence of feces in the cecum and rectum. Grade 1 also shows discontinous feces elsewhere in the colon (mild). In grade 2 (moderate) feces is present in all segments of the colon. Finally, grade 3 (severe) shows continous feces in all segments with a dilated colon and rectal impaction.

Leech score was based on the total colon was divided into 3 part; right, left, and rectosigmoid colon ${ }^{(13)}$. Leech score system assigned 0 point if no stool was ever observed, 1 point if a small amount of stool was observed, 2 points if a moderate amount of stool was observed, and 3 points if stool was seriously delayed.

This study was approved by ethical committee of Ahvaz Jundishapur University of Medical Sciences.

\section{Statistical analysis}

Statistician was blind to the aim of the study. Analysis was done with SPSS version 16.0 (Chicago, IL, USA). Independent sample t-test and Chi-square was used for comparison for quantitative and qualitative variables respectively. ROC curve was plotted for diagnostic accuracy of Barr, Leech, and Blethyn scores.

\section{RESULTS}

In this study 204 children (boy $=83$, girl=121) with mean age $68.92 \pm 33.68$ months were included. Of 204 children, 102 were case and 102 were control. Mean age of case and control group were $68.39 \pm 33.48$ months and $69.46 \pm 32.60$ months respectively $(P=0.82)$. Of case and control groups, $38.2 \%$ and $43.1 \%$ were boys respectively $(P=0.47)$.

Duration of abdominal pain was significantly longer in case compared to control group $(P<0.0001)$ (Table 1). There was significant difference between case and control in terms of defecation pattern $(P<0.0001)$. Difficulty in defecation was present in $64(62.7 \%)$ of case versus $23(22.5 \%)$ of control which was statistically significant $(P=0.000)$. There was no guarding in physical examination in both case and control group. Rigidity was not found in case and control group. Results of digital rectal examination was significantly difference between case and control. There was significant difference between case and control regarding to Barr $(P<0.0001)$, Blethyn $(P<0.0001)$, and Leech score $(P<0.0001)$ (Table 2). Diagnostic accuracy of Barr scoring system was $87 \%$ in our study. If score $>11$, sensitivity and specificity was $83 \%$ and $79 \%$ respectively. Diagnostic accuracy of Leech scoring system was $90 \%$ according to our study. If score $>9$, specificity and sensitivity will be $80 \%$ and $92 \%$ respectively. Blethyn scoring system had diagnostic accuracy about $78 \%$ in diagnosis of functional constipation in children. Sensitivity and specificity of Blethyn score was $79 \%$ and $92 \%$ respectively if score $>2$. Result of ROC curve were shown in Figures 1-3. According to Figures 1-3, sensitivity of Leech score was higher than others. Also, sensitivity of Blethyn score was lower than other systems.

TABLE 1. Duration of abdominal pain, Defecation pattern, and rectal examination between case and control

\begin{tabular}{|c|c|c|c|c|}
\hline & & $\begin{array}{c}\text { Children } \\
\text { with } \\
\text { constipation }\end{array}$ & $\begin{array}{l}\text { Children } \\
\text { without } \\
\text { constipation }\end{array}$ & $P$ value \\
\hline \multirow{4}{*}{$\begin{array}{l}\text { Duration of } \\
\text { abdominal } \\
\text { pain }\end{array}$} & $48 \mathrm{hr}$ & $27(26.5 \%)$ & $73(71.6 \%)$ & \multirow{4}{*}{$<0.0001$} \\
\hline & 1 week & $32(31.4 \%)$ & $29(19.6 \%)$ & \\
\hline & 1 months & $29(28.4 \%)$ & $7(6.9 \%)$ & \\
\hline & $>1$ month & $14(13.7 \%)$ & $2(2 \%)$ & \\
\hline \multirow{3}{*}{$\begin{array}{l}\text { Defecation } \\
\text { pattern }\end{array}$} & $\begin{array}{c}\text { Daily } \\
\text { defecation }\end{array}$ & $2(2 \%)$ & $21(20.6 \%)$ & \multirow{3}{*}{$<0.0001$} \\
\hline & $\begin{array}{c}>3 \text { defecation / } \\
\text { week }\end{array}$ & $7(6.9 \%)$ & $69(67.6 \%)$ & \\
\hline & $\begin{array}{c}<3 \text { defecation / } \\
\text { week }\end{array}$ & $93(91.2 \%)$ & $12(11.8 \%)$ & \\
\hline \multirow{3}{*}{$\begin{array}{l}\text { Rectal } \\
\text { examination }\end{array}$} & Empty & $2(2 \%)$ & $36(35.3 \%)$ & \multirow{3}{*}{$<0.0001$} \\
\hline & Soft feces & $10(9.8 \%)$ & $43(42.2 \%)$ & \\
\hline & Hard feces & $90(88.2 \%)$ & $23(22.5 \%)$ & \\
\hline
\end{tabular}


TABLE 2. Scoring system in case and control group

\begin{tabular}{cccccc}
\hline $\boldsymbol{P}$ value & Mean \pm SD & Max & Min & Group & $\begin{array}{c}\text { Scoring } \\
\text { system }\end{array}$ \\
\hline$<0.0001$ & $11.05 \pm 2.177$ & 15 & 5 & Case & Leech \\
& $5.67 \pm 3.228$ & 15 & 0 & Control & \\
& $14.86 \pm 3.546$ & 24 & 9 & Case & Barr \\
$<0.0001$ & $7.16 \pm 5.597$ & 22 & 0 & Control & \\
& $1.97 \pm 0.667$ & 3 & 1 & Case & Blethyn \\
$<0.0001$ & $1.04 \pm 0.900$ & 3 & 0 & Control & \\
\hline
\end{tabular}

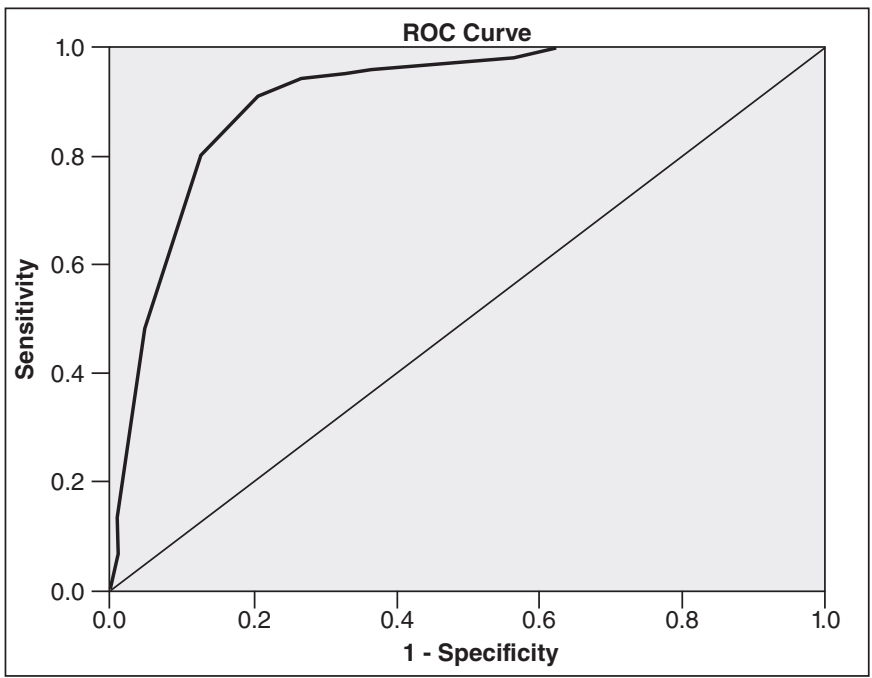

FIGURE 1. Leech score in diagnosis of functional constipation. $P<0.0001$

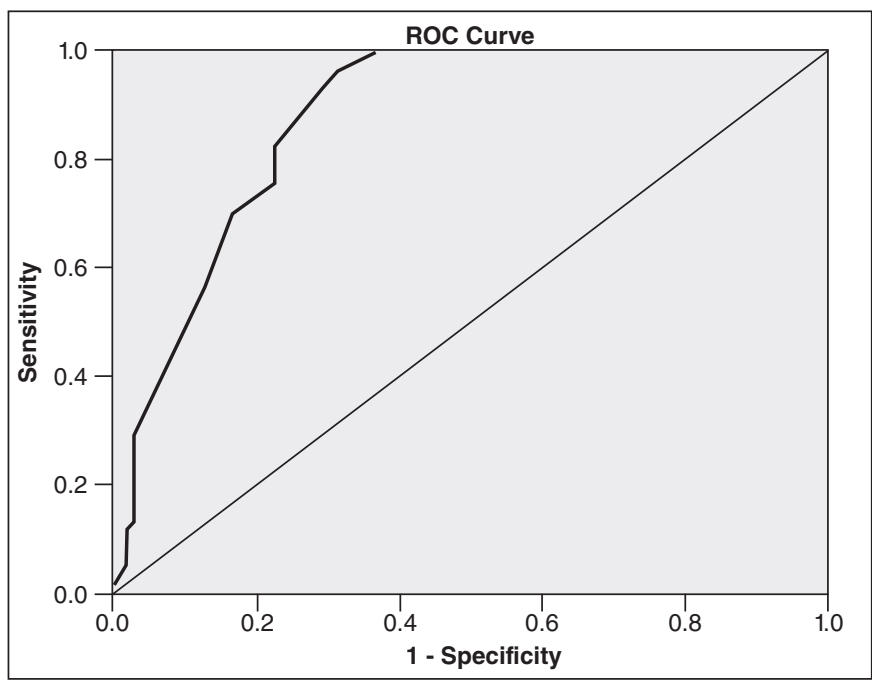

FIGURE 2. Barr score in diagnosis of children functional constipation. $P<0.0001$

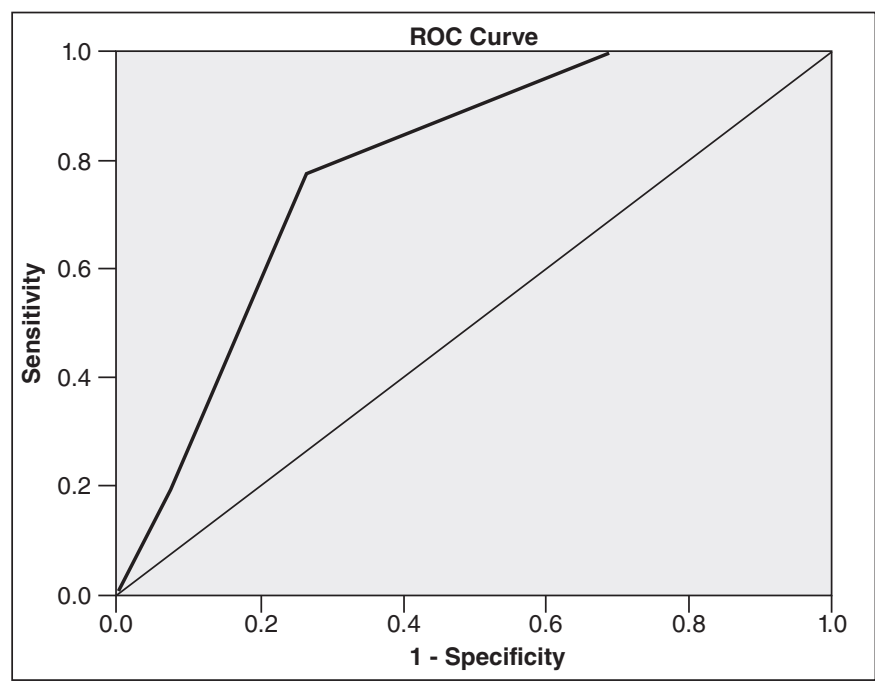

FIGURE 3. Blethyn score in diagnosis of functional constipation. $P<0.0001$

In our study, cut off value of leech score was $>=9$ in $92.2 \%$ of cases $(11.04 \pm 2.1)$. Cut off value of barr score in $97.1 \%$ of cases were $>=10$ (Table 3 ). Cut off value for Blethyn score was 2.

TABLE 3. Cut off value for Leech and Barr Scoring system

\begin{tabular}{lcccc}
\hline & \multicolumn{2}{c}{ Leech score } & \multicolumn{2}{c}{ Barr score } \\
& Mean & Cutoff $>9$ & Mean & Cutoff $>10$ \\
\hline Case & $11.04 \pm 2.1$ & $92.2 \%$ & $14.8 \pm 3.5$ & $97.1 \%$ \\
Control & $5.66 \pm 3.22$ & $20.6 \%$ & $7.15 \pm 5.59$ & $31.4 \%$ \\
\hline
\end{tabular}

\section{DISCUSSION AND CONCLUSION}

Diagnostic accuracy of Barr scoring system was $87 \%$ in our study. If score $>11$, sensitivity and specificity was $83 \%$ and $79 \%$ respectively. Another study recommended Barr score as a useful in diagnosis and also response to treatment of fecal impaction in children ${ }^{(7)}$. In the study by Beckmann et al., sensitivity and specificity was $77 \%$ and $35 \%$ respectively ${ }^{(2)}$. Pensabene et al. reported sensitivity and specificity of $75 \%$ and $48 \%$ respectively ${ }^{(16)}$. Specificity of Beckmann et al. and Pensabene et al. studies were significantly lower than our study. Benninga et al., in their study showed that abdominal radiograph, even when assessed with the Barr-score is unreliable in diagnosis of constipation ${ }^{(3)}$. This difference may be due to difference in mean age of sample of above studies.

Diagnostic accuracy of Leech scoring system was $90 \%$ according to our study. If score $>9$, specificity and sensitivity will be $80 \%$ and $92 \%$ respectively. Leech et al. reported sensitivity and specificity were $76 \%$ and $75 \%$ respectively ${ }^{(16)}$. Pensabene et al. reported sensitivity and specificity of Leech score $57 \%$ and $74 \%$ respectively ${ }^{(16)}$. The result of our study and Leech et al. ${ }^{(13)}$ study was similar. 
Koh et al. showed that Leech score is a simple and useful method for evaluation and follow up of fecal impaction in children $^{(12)}$. Koh et al. also reported that there is significant association between Leech scoring system and defecation frequency or abdominal pain ${ }^{(12)}$. In the study by Moon et al. on patients after stroke, they showed significant correlation between Leech score and constipation score ${ }^{(15)}$.

In our study, Blethyn scoring system had diagnostic accuracy about $78 \%$ in diagnosis of functional constipation in children. Sensitivity and specificity of Blethyn score was $79 \%$ and $92 \%$ respectively if score $>2$. Blethyn et al. on their study found radiography had $80 \%$ accuracy in diagnosis of functional constipation in children ${ }^{(5)}$. The results of two studies were similar. Jackson et al. studied 98 radiograph from 53 children ${ }^{(11)}$. In the study by Jackson et al., they showed moderate diagnostic accuracy for Blethyn; and hence is not recommended as a useful modality for assessment of constipation $^{(11)}$. Summary of other studies were included in Table 4.
As shown above there is controversies about usefulness of Barr, Blethyn, and Leech score for evaluation and follow up of fecal impaction in children. Age of the cases in above studies were different. Beckmann studied children aged 2-12 years old ${ }^{(2)}$. Leech et al. included infant aged 1 month to children aged 14 years old ${ }^{(13)}$. Benninga et al. studied children aged 5-14 years $^{(3)}$. In the current study, children aged 2-14 years were included. This difference in the age range may be the cause of different results in sensitivity and specificity of scores.

Barr, Blethyn and Leech scores were significantly higher in children with abdominal pain and constipation in contrast to children with abdominal pain and without constipation. Sensitivity of Leech score was more than Barr and Blethyn scoring systems. Specificity of Blethyn score was more than Bar and Leech score. More studies are required for better conclusion.

TABLE 4. Sensitivity and specificity of plain abdominal radiography in diagnosis of constipation compared to our study

\begin{tabular}{|c|c|c|c|c|c|c|c|}
\hline Specificity & Sensitivity & Mean age (yr) & Sample size & Place of study & $\begin{array}{l}\text { Year of } \\
\text { study }\end{array}$ & Scoring system & Study \\
\hline 90 & 80 & 8.4 & 42 & Boston, USA & 1979 & Barr & Barr et al. ${ }^{(1)}$ \\
\hline 43 & 60 & 8 & 101 & Amsterdam, Netherland & 1995 & Barr & Benninga et al..$^{(3)}$ \\
\hline 35 & 77 & 7.9 & 251 & Milwaukee, USA & 2001 & & Beckmann et al. ${ }^{(2)}$ \\
\hline $\operatorname{Barr}=48$ & Barr $=75$ & & & & & & \\
\hline Leech $=74$ & Leech $=57$ & & 160 & Boston, USA & 2010 & Leech & Pensabene et al. ${ }^{(16)}$ \\
\hline Barr $=79$ & Barr $=83$ & & & & & Barr & \\
\hline $\begin{array}{l}\text { Leech }=80 \\
\text { Blethyn }=92\end{array}$ & $\begin{array}{c}\text { Leech }=92 \\
\text { Blethyn }=79\end{array}$ & & $\begin{array}{c}204 \\
\text { (cases }=102, \\
\text { control=102) }\end{array}$ & Ahvaz, Iran & 2014 & $\begin{array}{c}\text { Leech } \\
\text { Blethyn }\end{array}$ & $\begin{array}{l}\text { Rezazadeh et al. } \\
\text { (Current study) }\end{array}$ \\
\hline
\end{tabular}

\section{ACKNOWLEDGMENT}

Data used in this manuscript was from general phyician thesis of Dr. Farzaneh Chahardahcherik and supported by research affair of Ahvaz Jundishapur University of Medical Sciences.

\section{Authors' contributions}

Rezazadeh A and Tahmasebi M: interpretation of radiography. Chahardahcherik F: data collection and writing the draft of article. Sadjadei N: revaluation of the patients and interpretation of radiologic findings. Javaherizadeh $\mathrm{H}$ : main idea and revision of the manuscript. Yavarahmadi MH: data collection and writing the draft of proposal. 
Rezazadeh A, Javaherizadeh H, Chahardahcherik F, Yavarahmadi MH, Sadjadei N, Tahmasebi M. Confiabilidade de pontuação dos escores de Barr, Leech e Blethyn no uso de radiografia simples na determinação da impactação fecal em crianças com e sem constipação. Arq Gastroenterol. 2016,53(3):141-5.

RESUMO - Contexto - Diversos métodos de pontuação utilizando a radiografia simples foram desenvolvidos para a avaliação de retenção fecal em crianças. Há controvérsias sobre a especificidade e sensibilidade destes sistemas de pontuação. Objetivo - O objetivo deste estudo foi avaliar os sistemas de escore Barr, Blethyn e Leech na avaliação do conteúdo fecal pela radiografia simples. Métodos - Estudo de caso controle em crianças com idade entre 2-14 anos, com dor abdominal que consultaram o Abuzar children's Hospital of Ahvaz University of Medical Sciences, durante o outono. Crianças com história prévia de cirurgia abdominal, com qualquer doença sistêmica, incluindo anemia falciforme, foram excluídas. Crianças com constipação foram inseridas no estudo e crianças sem constipação inseridas no grupo controle. Pacientes sem critérios de exclusão foram examinados por médico que ignorava o objeto do estudo. Foram realizadas história clínica e exame físico cuidadosos. Foram registradas as características demográficas, a história do problema gastrointestinal, a duração da dor abdominal, os hábitos intestinais e evacuatórios, a consistência das fezes (duras, amolecidas), e os resultados do exame físico. Os Critérios de Roma III foram usados para a definição de constipação. Radiografia simples do abdômen foi ordenada para cada paciente. Foram calculados os escores de Baar, Leech e Blethyn para cada paciente. Resultados - Foram incluídas neste estudo 102 crianças com constipação funcional e 102 crianças sem constipação como controle. A idade média com desvio padrão para o grupo paciente foi de $68.39 \pm 34.88$ e de 69.46 \pm 32.60 para o grupo controle $(P=0.82$ ). O escore de Leech (média $\pm D P$ ) foi de $11.05 \pm 2.1777$ para pacientes e de $5.67 \pm 3.228$ para o grupo controle $(P<0.0001)$. A pontuação de Barr (média \pm DP) foi $14.86 \pm 3.54$ para pacientes e de $7.16 \pm 5.59$ para o grupo controle $(P=<0.0001)$. $O$ escore Blethyn (média \pm DP) foi de $1.97 \pm 0.667$ para pacientes e de $1.04 \pm 0.900$ para o grupo controle $(P=0.000)$. A sensibilidade e especificidade para o escore de Baar foi de $83 \%$ e $79 \%$ respectivamente. Para o escore de Leech foi de $92 \%$ de sensibilidade e $80 \%$ de especificidade. O escore de Blethyn resultou em $79 \%$ de sensibilidade e especificidade de $92 \%$. Conclusão - As pontuações de Baar, Blethyn e Leech foram significativamente maiores em crianças com dor abdominal e constipação em contraste com as crianças com dor abdominal e sem constipação. A sensibilidade de pontuação Leech foi maior do que os sistemas de pontuação Barr e Blethyn. Escore de Blethyn teve mais especificidade que as pontuações Barr e Leech.

DESCRITORES - Constipação intestinal. Saúde da Criança. Dor abdominal. Raios X. Encoprese. Impacção fecal.

\section{REFERENCES}

1. Barr RG, Levine MD, Wilkinson RH, Mulvihill D. Chronic and Occult Stool Retention A Clinical Tool for Its Evaluation in School-Aged Children. Clin Pediatr. 1979;18:674-86.

2. Beckmann KR, Hennes H, Sty JR, Walsh-Kelly CM. Accuracy of clinical variables in the identification of radiographically proven constipation in children. WMJ. 2000;100:33-6.

3. Benninga MA, Buller HA, Staalman CR, Gubler FM, Bossuyt PM, van der Plas RN, et al. Defaecation disorders in children, colonic transit time versus the Barr-score. Eur J Pediatr. 1995;154:277-84.

4. Berger MY, Tabbers MM, Kurver MJ, Boluyt N, Benninga MA. Value of abdominal radiography, colonic transit time, and rectal ultrasound scanning in the diagnosis of idiopathic constipation in children: a systematic review. J Pediatr. 2012;161:44-50. e2.

5. Blethyn AJ, Verrier Jones K, Newcombe R, Roberts GM, Jenkins HR. Radiological assessment of constipation. Arch Dis Child. 1995;73:532-3.

6. Candy D, Paul S. Go with the flow: in childhood constipation. J Fam Health Care. 2010;21:35,7-8, 40-1 passim.

7. Cunha TB, Tahan S, Soares MF, Lederman HM, Morais MB. Abdominal radiograph in the assessment of fecal impaction in children with functional constipation: comparing three scoring systems. J Pediatr(Rio J). 2012;88:317-22.

8. de Morais MB, Tahan S. Constipação intestinal. Pediatr Mod. 2009;45:79-98.

9. Hyman PE, Milla PJ, Benninga MA, Davidson GP, Fleisher DF, Taminiau J. Childhood functional gastrointestinal disorders: neonate/toddler. Gastroenterology. 2006;130:1519-26.
10. Issenman RM, Hewson S, Pirhonen D, Taylor W, Tirosh A. Are chronic digestive complaints the result of abnormal dietary patterns?: Diet and digestive complaints in children at 22 and 40 months of age. Am J Dis Child. 1987;141:679-82.

11. Jackson CR, Lee RE, Wylie AB, Adams C, Jaffray B. Diagnostic accuracy of the Barr and Blethyn radiological scoring systems for childhood constipation assessed using colonic transit time as the gold standard. Pediatr Radiol. 2009;39:664-7.

12. Koh H, Lee MJ, Kim MJ, Shin JI, Chung KS. Simple diagnostic approach to childhood fecal retention using the Leech score and Bristol stool form scale in medical practice. J Gastroenterol Hepatol. 2010;25:334-8.

13. Leech SC, McHugh K, Sullivan P. Evaluation of a method of assessing faecal loading on plain abdominal radiographs in children. Pediatr Radiol. 1999;29:255-8.

14. Lisboa VCA, Felizola MCM, Martins LAN, Tahan S, Neto UF, de Morais MB. Aggressiveness and hostility in the family environment and chronic constipation in children. Dig Dis Sci. 2008;53:2458-63.

15. Moon HJ, Noh SE, Kim JH, Joo MC. Diagnostic value of plain abdominal radiography in stroke patients with bowel dysfunction. Ann Rehabil Med. 2015;39:243-52.

16. Pensabene L, Buonomo C, Fishman L, Chitkara D, Nurko S. Lack of utility of abdominal $\mathrm{x}$-rays in the evaluation of children with constipation: comparison of different scoring methods. J Pediatr Gastroenterol Nutr. 2010;51:155.

17. Rasquin-Weber A, Hyman P, Cucchiara S, Fleisher D, Hyams J, Milla P, et al Childhood functional gastrointestinal disorders. Gut. 1999;45(Suppl 2):II60-II8

18. Rasquin A, Di Lorenzo C, Forbes D, Guiraldes E, Hyams JS, Staiano A, et al. Childhood functional gastrointestinal disorders: child/adolescent. Gastroenterology. 2006;130:1527-37.

19. Yong D, Beattie R. Normal bowel habit and prevalence of constipation in primary-school children. Ambulatory Child Health. 1998;4:277-82. 